\title{
Penentuan Musim Tanam Berdasarkan Perhitungan Neraca Air Lahan di Daerah Saumlaki, Pulau Yamdena
}

\author{
Determination of Growing Seasons Based on Land Water Balance in Saumlaki \\ Area, Yamdena Island
}

\author{
Jenly F. Uspessy ${ }^{1}$, Semuel Laimeheriwa ${ }^{2, *}$, Jacob R. Patty ${ }^{2}$ \\ ${ }^{1}$ Program Studi Agroteknologi, Jurusan Budidaya Pertanian, Fakultas Pertanian, Universitas Pattimura, Jl. Ir. M. Putuhena, Kampus \\ Poka, Ambon 97233, Indonesia \\ ${ }^{2}$ Jurusan Budidaya Pertanian, Fakultas Pertanian, Universitas Pattimura Jl. I. M. Puttuhena, Kampus Poka, Ambon 97233, Indonesia \\ ${ }^{*}$ E-mail Penulis Korespondensi: laimeheriwasamuel@yahoo.co.id
}

\begin{abstract}
Climate information/data of a region plays an important role in agricultural development in the region, because by utilizing the knowledge of the relationship between crops and climate, forecasts can be made of planting time, harvest time, drought (water deficit), flood (water surplus), pest attack and disease, determining the appropriate type of crop, and so on. The purpose of this study was to assess the presence of soil water and to determine the growing season in the Saumlaki area based on two rainfall conditions. This study used monthly rainfall data for 30 years (1990-2019) as well as other climatic data, such as air temperature, air humidity, sunshine duration and wind speed for 15 years (2005-2019). Computing of the water balance was carried out using Thornthwaite-Mather Method, and determination of growing season using soil water in optimum condition. Based on the calculation of the land water balance in the rainfall conditions there was a $75 \%$ chance of being surpassed by the groundwater deficit in the Saumlaki area which lasted for 6 months (June-November), whereas the value increases by $183 \mathrm{~mm}$ or $45.52 \%$ compared to normal conditions, that was from $402 \mathrm{~mm}$ to $585 \mathrm{~mm}$. On the other hand, the groundwater surplus lasted only a month (May) and tended to decrease by $686 \mathrm{~mm}$ or $97.03 \%$ compared to normal conditions, from $707 \mathrm{~mm}$ to $21 \mathrm{~mm}$. The optimum soil water content for plants in rainfall conditions was 75\% chance of lasting for 6 months (January-June); 2 months shorter than the normal 8 months (December-July). In conditions of 75\% chance of rainfall, the growing season in the Saumlaki area lasted for 7 months (December-June); a month shorter than the growing season in normal rainfall conditions of 8 months (December-July).
\end{abstract}

Keywords: growing season, land water balance, rainfall, Saumlaki area

\begin{abstract}
ABSTRAK
Informasi/data iklim suatu tempat berperan penting dalam pengembangan pertanian di wilayah tersebut, karena dengan memanfaatkan pengetahuan tentang hubungan antara tanaman dan iklim dapatlah dibuat prakiraan waktu tanam, waktu panen, kejadian kekeringan (defisit air), banjir (surplus air), serangan hama dan penyakit, penentuan jenis tanaman yang sesuai, dan sebagainya. Tujuan penelitian ini untuk menilai keberadaan air tanah dan menentukan musim tanam di Daerah Saumlaki pada dua kondisi curah hujan. Penelitian ini menggunakan data curah hujan bulanan selama 30 tahun (1990-2019) dan data iklim lainnya (suhu udara, kelembaban udara, lama penyinaran matahari kecepatan angin) selama 15 tahun (2005-2019). Perhitungan neraca air lahan menggunakan metode Thornthwaite-Mather, dan musim tanam ditentukan berdasarkan kondisi air tanah optimum. Berdasarkan perhitungan neraca air lahan pada kondisi curah hujan berpeluang 75\% untuk dilampaui, defisit air tanah di daerah Saumlaki berlangsung selama selama 6 bulan (Juni-November) yaitu nilainya bertambah sebesar $183 \mathrm{~mm}(45,52 \%)$ dibandingkan kondisi normalnya, yaitu dari $402 \mathrm{~mm}$ menjadi $585 \mathrm{~mm}$. Sebaliknya surplus air tanah berlangsung hanya sebulan (Mei) dan cenderung berkurang sebesar 686 mm (97,03\%) dibandingkan kondisi normalnya, yaitu dari 707 mm menjadi $21 \mathrm{~mm}$. Kadar air tanah yang optimum bagi tanaman pada kondisi curah hujan peluang 75\% berlangsung selama 6 bulan (Januari-Juni); lebih pendek 2 bulan dibandingkan kondisi normalnya 8 bulan (Desember-Juli). Pada kondisi curah hujan peluang 75\%, musim tanam di daerah Saumlaki berlangsung selama 7 bulan (Desember-Juni); sebulan lebih pendek dibandingkan musim tanam pada kondisi curah hujan normalnya 8 bulan (Desember-Juli).
\end{abstract}

Kata kunci : curah hujan, daerah Saumlaki, musim tanam, neraca air lahan 


\section{PENDAHULUAN}

Indonesia memiliki wilayah yang luas dan beragam dan setiap daerah memiliki keadaan yang khas, termasuk keadaan iklimnya. Hal ini menyebabkan interaksi antara tanaman dengan kondisi iklim/cuaca berbeda antara suatu tempat dengan tempat lainnya. Informasi keadaan iklim suatu tempat memegang peranan penting bagi bentuk dan pengembangan pertanian tempat tersebut, karena dengan memanfaatkan pengetahuan tentang hubungan antara tanaman dan iklim maka dapatlah dibuat prakiraan waktu tanam, waktu panen, kejadian kekeringan (defisit air), banjir (surplus air), serangan hama dan penyakit, penentuan jenis tanaman yang sesuai, dan sebagainya.

Data iklim/cuaca yang tercatat atau yang diambil dari stasiun iklim yang ada di suatu lokasi tidak dapat langsung digunakan. Data iklim yang diperoleh umumnya dalam bentuk nilai harian atau nilai bulanan selama beberapa tahun. Data tersebut perlu dianalisis dan dinterpretasi untuk mengetahui dan memahami karakteristiknya, sehingga dapat menjadi informasi yang aplikatif untuk dimanfaatkan dalam berbagai sektor pembangunan, diantaranya dalam bidang pertanian adalah menyesuaikan sistem usahatani dan paket teknologinya dengan kondisi iklim setempat (Laimeheriwa, 2015).

Pada pertanian lahan kering, komponen curah hujan merupakan satu-satunya komponen masukan air bagi lahan pertanian. Untuk itu, dalam penggunaan informasi/data curah hujan untuk berbagai analisis agroklimat wilayah perlu dipertimbangkan karakteristik curah hujan tersebut. Dalam penerapannya menurut Bey dan Las (1991), hasil analisis agroklimat yang menggunakan nilai curah hujan rata-rata bulanan cenderung hanya memberikan pola iklim tertentu. Data tersebut dapat berguna untuk mengindikasikan zona agroklimat yang bersifat homogen tetapi tidak dapat memberikan informasi tentang keragaman curah hujan. Selain berkeragaman tinggi, curah hujan ini sering eratik dan sporadis. Pada bulan yang sama dan tahun yang berbeda sering dijumpai perbedaan yang sangat tinggi, dan waktu serta zone jatuhnya hujan sulit diduga. Oleh sebab itu, penggunaan nilai peluang dalam menduga curah hujan sangat diperlukan untuk menghindari resiko kekeringan akibat over estimate atau pemborosan sumber daya air/hujan dan waktu akibat under estimate.

Perbedaan kondisi iklim di setiap daerah akan memberikan implikasi yang berbeda terhadap kondisi neraca air lahan di masing-masing daerah. Oleh karena kondisi iklim yang bervariasi, maka kondisi air tanah secara periodik (minimal kondisi bulanan) melalui perhitungan neraca air lahan di tiap daerah/lokasi perlu diketahui. Manfaatnya antara lain memberikan masukan kepada perencana dalam menyusun tindakan pengelolaan pertanian yang lebih baik dengan memperhatikan iklim setempat. Disamping itu, hasil perhitungan neraca air lahan suatu daerah dapat memberikan gambaran tentang periode musim tanam di daerah tersebut; dengan mempertimbangkan kadar air tanah dalam kondisi optimum, periode defisit air dan kebutuhan air tanaman pada berbagai tahap perkembangan tanaman.

Salah satu contoh metode perhitungan neraca air adalah yang dibuat berdasarkan sistem tata buku Thorntwaite dan Mather (1957). Metode ini telah diterapkan pada beberapa penelitian sebelumnya, diantaranya yaitu analisis neraca air dalam penentuan potensi musim tanam tanaman pangan di Provinsi Banten (Hidayat et al., 2006), analisis untuk pengembangan tanaman pangan pada kondisi iklim yang berbeda (Mardawilis et al., 2011), pemodelan neraca air tanah yang dilakukan untuk pendugaan surplus dan defisit air guna pertumbuhan tanaman pangan di Kabupaten Merauke Papua (Djufry, 2012), analisis neraca air lahan untuk tanaman padi dan jagung di Kota Bengkulu (Paski et al., 2017), penelitian untuk melihat pergeseran jadwal tanam di Daerah Irigasi Cimandiri (Sofia et al., 2019), serta hasil penelitian di wilayah Maluku yang menggunakan pertimbangan hasil perhitungan neraca air lahan untuk menentukan musim tanam diantaranya oleh Nangimah et al. (2018) di Daerah Waeapo Pulau Buru dan Laimeheriwa et al. (2019) di Pulau Ambon.

Penelitian ini bertujuan untuk menilai keberadaan air tanah dan menentukan musim tanam di Daerah Saumlaki pada dua kondisi curah hujan.

\section{BAHAN DAN METODE}

\section{Tempat dan Waktu}

Penelitian ini dilaksanakan di Daerah Saumlaki Kabupaten Kepulauan Tanimbar yang berlangsung selama 2 (dua) bulan; Juli dan Agustus 2020.

\section{Bahan dan Alat}

Bahan yang digunakan dalam penelitian ini berupa: (1) data iklim, (2) data tanah, dan (3) data letak wilayah (elevasi dan lintang), serta data penunjang lainnya. Data yang tidak tersedia akan dibangkitkan melalui pendekatan statistik-matematik berdasarkan indikator fisik wilayah. Alat yang digunakan adalah: MS Word 2010, MS Excel 2010, Program CROPWAT 8.0, komputer, dan alat tulis menulis.

\section{Pengumpulan Data} meliputi:

Data yang dikumpulkan pada penelitian ini

1. Data iklim hasil pengamatan Stasiun Meteorologi Saumlaki, terdiri dari: (i) curah hujan bulanan selama 30 tahun pengamatan; periode 1990-2019, dan (ii) data unsur iklim lainnya: suhu udara, kelembaban udara, lama penyinaran surya dan kecepatan angin; data 15 tahun terakhir periode 2005-2019. 
2. Data jenis tanah yang dominan di daerah Saumlaki merujuk pada berbagai hasil penelitian yang pernah ada.

3. Data elevasi, lintang dan bujur serta data penunjang lainnya diperoleh berbagai referensi.

\section{Metode Analisis}

Dalam penelitian ini dilakukan analisis data untuk: (1) menentukan curah hujan rata-rata, (2) menentukan curah hujan berpeluang 75 persen untuk dilampaui, (3) perhitungan neraca air lahan, dan (4) penentuan musim tanam wilayah.

\section{Perhitungan Curah Hujan Rata-Rata (Pb)}

Perhitungan curah hujan rata-rata wilayah menggunakan data curah hujan time series bulanan selama 30 tahun pengamatan (1990-2019). Penggunaan data curah hujan 30 tahun representatif untuk menggambarkan kondisi iklim suatu wilayah (Schulz, 1980; Manik, 2014). Perhitungan nilai curah hujan ratarata menggunakan rumus yang umum, yaitu teknik ratarata aljabar, sebagai berikut:

$$
\mathbf{P b}=\sum_{\mathrm{i}=1}^{n} \mathrm{Pi} / \mathrm{n}
$$

dimana: $\mathrm{Pb}=$ Curah hujan rata-rata bulanan $(\mathrm{mm}) ; \mathrm{Pi}=$ Curah hujan bulan tertentu pada tahun ke-i; $\mathrm{n}=$ Jumlah tahun pengamatan

\section{Penentuan Curah Hujan Berpeluang 75\% Untuk Dilampaui $\left(\mathbf{P}_{75}\right)$}

Perhitungan nilai curah pada tingkat peluang kejadian $75 \%$ untuk dilampaui menggunakan metode urut berjenjang (ranking order method) dengan persamaan sebagai berikut (Patty, 1988):

$$
\mathrm{Fa}=100 \mathrm{~m} /(\mathrm{N}+1)
$$

dimana: $\mathrm{Fa}=$ tingkat peluang $(\%) ; \mathrm{m}=$ nomor urut data (ranking) dari nilai curah hujan terbesar ke terkecil pada periode sama (misalnya, minggu/bulan yang sama) pada suatu data time series/runut waktu; $\mathrm{N}=$ Jumlah tahun pengamatan

\section{Perhitungan Neraca Air Lahan}

Perhitungan neraca air lahan bulanan di Daerah Saumlaki menggunakan sistem tata buku (book keeping) yang dikemukakan oleh Thornthwaite dan Mather (1957). Perhitungan neraca air lahan dengan metode ini menggunakan data masukan curah hujan rata-rata dan curah hujan berpeluang $75 \%$ untuk dilampaui, serta data evapotranspirasi potensial yang dihitung menggunakan metode Penman-Monteith dengan Program CROPWAT 8.0. Data penunjang lainnya berupa nilai kapasitas lapang dan titik layu permanen, letak lintang dan bujur, dan lainnya.

\section{Penentuan Musim Tanam}

Musim tanam atau periode tumbuh tersedia merupakan periode dimana tanaman dapat tumbuh dan berkembang secara potensial berdasarkan kondisi lahan setempat. Penetapan musim tanam di Daerah Saumlaki didasarkan pada hasil perhitungan neraca air lahan pada dua kondisi curah hujan ( $\mathrm{Pb}$ dan $\mathrm{P}_{75}$ ), dengan tiga kriteria penentuannya, sebagai berikut:

1. Periode dimana kadar air tanah berada dalam kondisi optimum bagi pertumbuhan; dimana KATopt $=$ KAT $\geq$ TLP + 0,5 x WHC (Las, 1992),

2. Bulan/periode dimana tidak terjadi defisit air, dan

3. Rasio antara curah hujan (P) dengan evapotranspirasi potensial (ETp); jika pada bulan tertentu yaitu 1 (satu) bulan sebelum dan sesudah periode KATopt $\mathrm{P} / \mathrm{ETp} \geq 0,75$, maka bulan tersebut masuk dalam periode musim tanam.

Hasil penentuan periode musim tanam ini kemudian dilanjutkan dengan penentuan intensitas tanam beberapa tanaman umur pendek (sayuran dan tanaman pangan) yang biasanya diusahakan petani di Daerah Saumlaki (Kecamatan Tanimbar Selatan); dimana intensitas tanam sangat bergantung pada umur panen setiap jenis tanaman. Asumsi yang digunakan adalah tanaman ditanam dengan pola tanam monokultur.

\section{HASIL DAN PEMBAHASAN}

\section{Gambaran Umum Lokasi Penelitian}

\section{Letak dan luas}

Secara administratif pemerintahan, Daerah Saumlaki termasuk dalam wilayah Kecamatan Tanimbar Selatan Kabupaten Kepulauan Tanimbar dengan luas $825,69 \mathrm{~km}^{2}$; terdiri dari 11 desa. Secara astronomis wilayah ini berada pada $07^{\circ} 39^{\prime}-07^{\circ} 89^{\prime}$ Lintang Selatan dan $130^{\circ} 81^{\prime}-131^{\circ} 32^{\prime}$ Bujur Timur, dan secara geografis mempunyai batas-batas alam sebagai berikut (BPS, 2019):

- Sebelah utara : Kecamatan Wertamrian danKecamatan Wermaktian

- Sebelah selatan : Kecamatan Selaru

- Sebelah barat : Laut Banda, dan

- Sebelah timur : Laut Arafura.

\section{Biofisik Wilayah}

\section{Iklim}

Daerah Saumlaki termasuk daerah beriklim agak kering yang mirip dengan daerah semi arid tropic. Hasil analisis data seri iklim bulanan periode 19902019, seperti yang ditunjukkan pada Tabel 1 dan Tabel 2. 
Tabel 1. Kondisi ilkim bulanan daerah Saumlaki

\begin{tabular}{|c|c|c|c|c|c|c|c|c|}
\hline Bulan & $\begin{array}{l}\text { Curah } \\
\text { Hujan } \\
\text { (mm) }\end{array}$ & $\begin{array}{l}\text { Hari } \\
\text { Hujan } \\
\text { (hari) }\end{array}$ & $\begin{array}{l}\text { Suhu } \\
\text { Udara } \\
\text { Rataan } \\
\text { (C) }\end{array}$ & $\begin{array}{c}\text { Suhu } \\
\text { Udara } \\
\text { Maksimum } \\
\text { ("C) }\end{array}$ & $\begin{array}{l}\text { Suhu Udara } \\
\text { Minimum } \\
\text { (C) }\end{array}$ & $\begin{array}{c}\text { Kelembaban } \\
\text { Nisbi Udara } \\
(\%)\end{array}$ & $\begin{array}{c}\text { Lama } \\
\text { Penyinaran } \\
\text { Surya } \\
\text { (jam hari) }\end{array}$ & $\begin{array}{l}\text { Kecepatan } \\
\text { Angin Rataan } \\
\text { (km hari) }\end{array}$ \\
\hline Januari & 270 & 19 & 27,9 & 32,1 & 24,8 & 85 & 4,0 & 240 \\
\hline Februari & 257 & 17 & 28,0 & 32,2 & 24,6 & 85 & 4,5 & 208 \\
\hline Maret & 238 & 18 & 27,7 & 32,2 & 24,5 & 86 & 4,4 & 196 \\
\hline April & 258 & 17 & 27,7 & 31,6 & 24,5 & $\$ 4$ & 4,8 & 205 \\
\hline Me! & 330 & 18 & 27,5 & 30,8 & 24,8 & 82 & 5,0 & 320 \\
\hline Juni & 182 & 17 & 26,7 & 29,5 & 24,0 & 81 & 4,6 & 338 \\
\hline Juli & 69 & 13 & 26,2 & 29,0 & 23,7 & 80 & 5,1 & 389 \\
\hline Agustus & 25 & 7 & 26,2 & 29,3 & 23,6 & 77 & 6,7 & 359 \\
\hline September & 11 & 2 & 26,7 & 30,1 & 23,9 & 78 & 7,1 & 297 \\
\hline Oktober & 23 & 3 & 27,7 & 31,5 & 24,4 & 78 & 7,2 & 252 \\
\hline November & 60 & 6 & 28,7 & 33,0 & 24,9 & 78 & 6,1 & 169 \\
\hline Desember & 224 & 17 & 28,6 & 33,0 & 25,1 & 82 & 3,9 & 175 \\
\hline Tahunan & 1.947 & 155 & 27,5 & 31,2 & 24,4 & 81 & 5,3 & \\
\hline
\end{tabular}

Tabel 2. Nilai curah hujan peluang $75 \%\left(\mathrm{P}_{75}\right)$ dan evapotranspirasi potensial $\left(\mathrm{ET}_{\mathrm{p}}\right)$ daerah Saumlaki

\begin{tabular}{cccccccccccccc}
\hline Komponen & Jan & Feb & Mar & Apr & Mei & Jun & Jul & Ags & Sep & Okt & Nov & Des & Setahun \\
\hline P s & 206 & 167 & 131 & 155 & 159 & 65 & 40 & 6 & 0 & 0 & 8 & 141 & 1.078 \\
ETp & 132 & 123 & 130 & 123 & 129 & 118 & 129 & 152 & 154 & 167 & 152 & 133 & 1.642 \\
\hline
\end{tabular}

Sumber: Diolah dari data Klimatologi Stasiun Meteorologi Saumlaki periode 1990-2019

\section{Geologi dan bentuk wilayah}

Bentuk wilayah Daerah Saumlaki umumnya berupa dataran rendah dengan topografi datar (kelerengan 0-3\%) hingga bergelombang (kemiringan lereng 3-8\%) yang sangat dipengaruhi oleh kondisi geologi daerah, yaitu gamping coral padat yang terungkit (Tim Amdal Unpatti, 2018).

\section{Tanah}

Berdasarkan hasil pengamatan ciri morfologi di lapangan dan didukung data hasil analisis kimia, tanahtanah di kecamatan Tanimbar Selatan diantaranya yang dominan termasuk pada ordo Entisols, Inceptisols, Mollisols, Alfisols dan Ultisols (Tim Faperta Unpatti, 1995). Tanah-tanah ini bertekstur mulai dari lempung berpasir hingga lempung berliat.

\section{Kondisi Pertanian}

Komoditi pertanian yang umumnya diusahakan oleh masyarakat petani dan/atau pengguna lahan pertanian lainnya di wilayah Kecamatan Tanimbar Selatan pada tahun 2017 terdiri dari (BPS, 2019):

- Tanaman Pangan: padi ladang, jagung, ubi kayu, ubi jalar, ubian lain, kacang tanah, kacang hijau dan kacangan lain; total luas panen 472 ha.

- Hortikultura sayuran dengan luas panen 109 ha dan hortikultura buahan dengan total produksi 1.055 ton,

- Tanaman Perkebunan: kelapa (produksi 4.524 ton), coklat (produksi 2,8 ton), dan jambu mete (produksi 45,0 ton).

\section{Neraca Air Lahan}

Hasil perhitungan neraca air lahan Daerah Saumlaki pada kondisi curah hujan rata-rata dan curah hujan peluang $75 \%$ seperti yang disajikan masingmasing pada Tabel 3 dan 4 .

Tabel 3 menunjukkan bahwa pada kondisi curah hujan rata-rata, defisit air (D) yang terjadi di Daerah Saumlaki berlangsung selama 5 bulan (Juli-November) dengan kisaran defisit antara 9-130 $\mathrm{mm} /$ bulan dan total defisit $402 \mathrm{~mm} /$ tahun. Defisit air yang terjadi karena nilai potensial evapotrasnpirasi (ETp) melebihi nilai aktualnya (ETa) akibat curah hujan (P) yang rendah. Sementara itu, periode surplus air (S) berlangsung selama 6 bulan, yaitu Januari-Juni dengan kisaran 64$201 \mathrm{~mm}$ dan total surplus $707 \mathrm{~mm} /$ tahun. Surplus air yang terjadi selama musim hujan sangat bergantung pada selisih antara curah hujan dan evapotranspirasi potensial serta perubahan kadar air tanah tiap bulannya. Secara grafis periode defisit dan surplus air tanah di Daerah Saumlaki pada kondisi curah hujan rata-rata seperti yang disajikan pada Gambar 1 .

Hasil perhitungan neraca air lahan Daerah Saumlaki pada kondisi curah hujan berpeluang $75 \%$ untuk dilampaui (Tabel 4) menunjukkan bahwa defisit air berlangsung selama 6 bulan, dimulai awal musim kering (Juni) hingga akhir musim kering (November) dengan kisaran defisit antara 7-160 mm/bulan dan total defisit $585 \mathrm{~mm} /$ tahun. Kondisi defisit air ini nilainya cenderung bertambah sebesar $183 \mathrm{~mm}$ atau 45,52\% dibandingkan dengan kondisi curah hujan normal (ratarata). 
Tabel 3. Perhitungan neraca air lahan Daerah Saumlaki pada kondisi curah hujan rata-rata

\begin{tabular}{|c|c|c|c|c|c|c|c|c|c|}
\hline Bulan & $\mathbf{P}$ & $\mathrm{ETp}$ & P-Etp & APWL & KAT & dKAT & ETa & $\mathrm{D}$ & $\mathrm{S}$ \\
\hline Januari & 270 & 132 & 138 & & 320 & 73 & 132 & 0 & 65 \\
\hline Februari & 257 & 123 & 134 & & 320 & 0 & 123 & 0 & 134 \\
\hline Maret & 238 & 130 & 108 & & 320 & 0 & 130 & 0 & 108 \\
\hline April & 258 & 123 & 135 & & 320 & 0 & 123 & 0 & 135 \\
\hline Mei & 330 & 129 & 201 & & 320 & 0 & 129 & 0 & 201 \\
\hline Jun & 182 & 118 & 64 & & 320 & 0 & 118 & 0 & 64 \\
\hline Juli & 69 & 129 & -60 & -60 & 269 & -51 & 120 & 9 & 0 \\
\hline Agustus & 25 & 152 & -127 & -187 & 206 & -63 & 88 & 64 & 0 \\
\hline September & 11 & 154 & -143 & -330 & 174 & -32 & 43 & 111 & 0 \\
\hline Oktober & 23 & 167 & -144 & -474 & 160 & -14 & 37 & 130 & 0 \\
\hline November & 60 & 152 & -92 & -566 & 156 & -4 & 64 & 88 & 0 \\
\hline Desember & 224 & 133 & 91 & & 247 & 91 & 133 & 0 & 0 \\
\hline Setahun & 1.947 & 1.642 & & & & 0 & 1.240 & 402 & 707 \\
\hline
\end{tabular}

Keterangan: $\mathrm{P}=$ curah hujan $(\mathrm{mm}) ; \mathrm{ETp}=$ evapotranspirasi potensial $(\mathrm{mm}) ; \mathrm{APWL}=$ akumulasi air yang hilang secara potensial (mm); KAT=kandungan air tanah (mm); dKAT=perubahan kandungan air tanah (mm); ETa=evapotranspirasi aktual (mm); D=defisit air (mm); $\mathrm{KAT}=$ kandungan air

Tabel 4. Perhitungan neraca Air lahan Daerah Saumlaki pada kondisi curah hujan peluang $75 \%$

\begin{tabular}{|c|c|c|c|c|c|c|c|c|c|}
\hline Bulan & $\mathbf{P}_{75}$ & $\mathrm{ETp}$ & $\mathrm{P}_{75}$-Etp & APWL & KAT & dKAT & Eta & $\mathrm{D}$ & $\mathrm{S}$ \\
\hline Januari & 206 & 132 & 74 & & 235 & 74 & 132 & 0 & 0 \\
\hline Februari & 167 & 123 & 44 & & 278 & 44 & 123 & 0 & 0 \\
\hline Maret & 131 & 130 & 1 & & 279 & 1 & 130 & 0 & 0 \\
\hline April & 155 & 123 & 32 & & 311 & 32 & 123 & 0 & 0 \\
\hline Mei & 159 & 129 & 30 & & 320 & 9 & 129 & 0 & 21 \\
\hline Jun & 65 & 118 & -53 & -53 & 274 & -46 & 111 & 7 & 0 \\
\hline Juli & 40 & 129 & -89 & -142 & 223 & -51 & 91 & 38 & 0 \\
\hline Agustus & 6 & 152 & -146 & -288 & 181 & -42 & 48 & 104 & 0 \\
\hline September & 0 & 154 & -154 & -442 & 162 & -19 & 19 & 135 & 0 \\
\hline Oktober & 0 & 167 & -167 & -609 & 155 & -7 & 7 & 160 & 0 \\
\hline November & 8 & 152 & -144 & -753 & 152 & -3 & 11 & 141 & 0 \\
\hline Desember & 141 & 133 & 8 & & 160 & 8 & 133 & 0 & 0 \\
\hline Setahun & 1.078 & 1.642 & & & & 0 & 1.057 & 585 & 21 \\
\hline
\end{tabular}

Keterangan: $\mathrm{P}_{75}=$ curah hujan (mm); ETp=evapotranspirasi potensial (mm); APWL=akumulasi air yang hilang secara potensial (mm); KAT=kandungan air tanah (mm); dKAT=perubahan kandungan air tanah (mm); ETa=evapotranspirasi aktual (mm); D=defisit air (mm); $\mathrm{S}=$ surplus air $(\mathrm{mm})$.

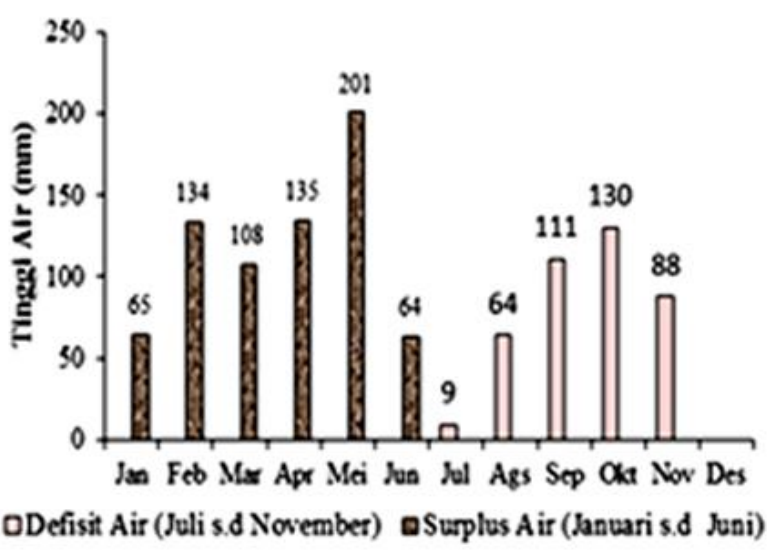

Gambar 1. Periode deficit dan surplus air di daerah Saumlaki pada kondisi curah hujan rata-rata
Periode surplus air berlangsung hanya dalam 1 bulan, yaitu pada saat puncak curah hujan di bulan Mei sebesar $21 \mathrm{~mm}$. Nampak bahwa surplus air yang terjadi nilainya cenderung berkurang cukup tajam sebesar 686 $\mathrm{mm}$ atau 97,03\% dibandingkan dengan kondisi curah hujan rata-rata.

Secara grafis periode defisit dan surplus air tanah di Daerah Saumlaki pada kondisi curah hujan berpeluang $75 \%$ untuk dilampaui seperti yang ditunjukkan pada Gambar 2.

\section{Musim Tanam}

Musim tanam atau periode tumbuh tersedia merupakan periode dimana tanaman dapat tumbuh dan berkembang secara potensial berdasarkan kondisi lahan setempat. 


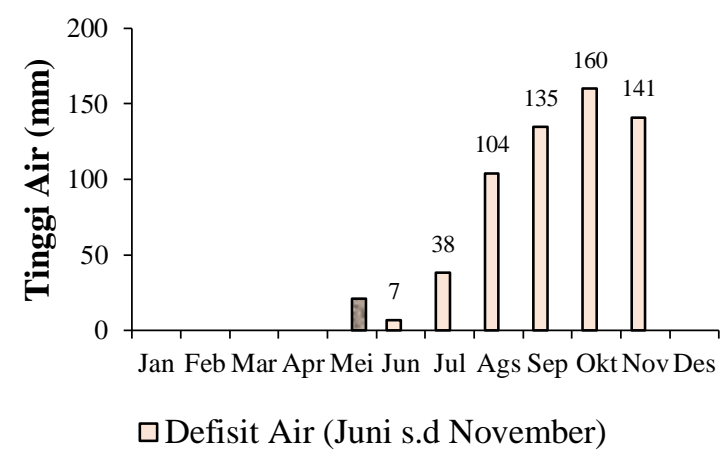

Gambar 2. Periode defisit dan surplus air di daerah Saumlaki pada kondisi curah hujan peluang $75 \%$

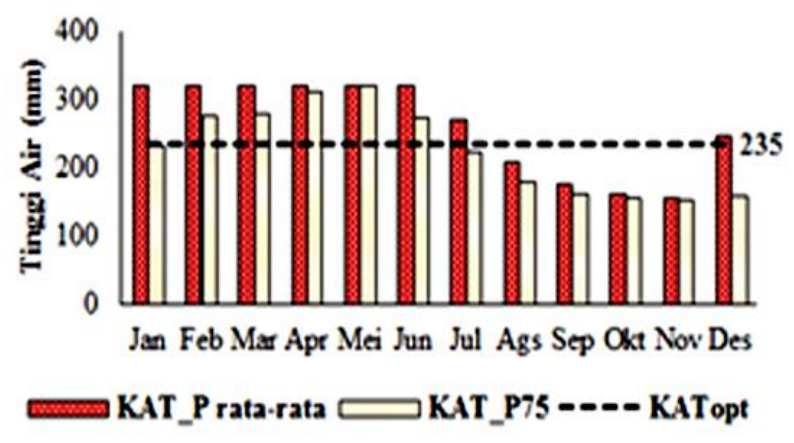

Gambar 3. Kadar air tanah pada kondisi curah hujan rata-rata dan curah hujan peluang $75 \%$

\begin{tabular}{|c|c|c|c|c|c|c|c|c|c|c|c|c|}
\hline Komponen & Jan & Feb & Mar & Apr & Mei & Jun & \begin{tabular}{|l|} 
Jul \\
\end{tabular} & Ags & Sep & Okt & \begin{tabular}{|l|} 
Nov \\
\end{tabular} & Des \\
\hline \multicolumn{13}{|c|}{ Curah Hujan Normal (rata-rata) } \\
\hline \multicolumn{13}{|c|}{ Periode KATopt } \\
\hline \multicolumn{13}{|c|}{ Periode Tanpa Defisit Air } \\
\hline Rasio: P Etp & & & & & & & & 0,16 & & & 0,39 & \\
\hline Musim Tanam & & & & & & & & & & & & \\
\hline \multicolumn{13}{|c|}{ Curah Hujan Peluang $75 \%$} \\
\hline \multicolumn{13}{|c|}{ Periode KATopt } \\
\hline \multicolumn{13}{|c|}{ Periode Tanpa Defisit Air } \\
\hline Rasio: $\mathrm{P}_{75}$ Etp & & & & & & & 0,31 & & & & 0,05 & \\
\hline Musim Tanam & & & & & & & & & & & & \\
\hline
\end{tabular}

Gambar 4. Penentuan musim tanam di daerah Saumlaki pada dua kondisi curah hujan

Tabel 5. Frekuensi tanam sayuran dan tanaman pangan di daerah Saumlaki pada dua kondisi curah hujan

\begin{tabular}{|c|c|c|}
\hline Umur Panen (bln) & Komoditi & Frekuensi Tanam (kali) \\
\hline \multicolumn{3}{|c|}{ Kondisi Cuah Hujan Noumal : Musim Tanam 8 bulan } \\
\hline 2 & jagung, kacang hijau, kacang panjang & $3-4$ \\
\hline 3 & $\begin{array}{l}\text { padi ladang, jagung, kacang hijau, kacang tanah, kedelai, } \\
\text { cabe, tomat, kubis, terong, buncis }\end{array}$ & $1-2$ \\
\hline 4 & ubi jalar, kacang tanah. kedelai, cabe, tomat, kubis, buncis & $1-2$ \\
\hline 5 & ubi jalar & 1 \\
\hline$\geq 6$ & ubi kayu & 1 \\
\hline \multicolumn{3}{|c|}{ Kondisi Cuah Hujan Peluang ${ }^{-50}$ : Musim Tanam - bulan } \\
\hline 2 & jagung. kacang hijau, kacang panjang & $2-3$ \\
\hline 3 & $\begin{array}{l}\text { padi ladang, jagung, kacang hijau, kacang tanah, kedelai, } \\
\text { cabe, tomat, kubis, terong, buncis }\end{array}$ & $1-2$ \\
\hline 4 & ubi jalar, kacang tanah, kedelai, cabe, tomat, kubis, buncis & 1 \\
\hline 5 & ubi jalar & 1 \\
\hline$\geq 6$ & ubi kayu & 1 \\
\hline
\end{tabular}

Penentuan musim tanam Daerah Saumlaki didasarkan pada pertimbangan: (1) KATopt, (2) defisit air, rasio P/ETp. Hasil penentuan musim tanam seperti yang ditunjukkan pada Gambar 4.

Gambar 5 menunjukkan bahwa periode musim tanam di Daerah Saumlaki pada kondisi curah hujan normal berlangsung selama 8 bulan (DesemberJuli),sedangkan pada kondisi curah hujan peluang $75 \%$, periode musim tanamberlangsung selama 7 bulan (Desember sampai Juni).
Berdasarkan hasil penentuan musim tanam pada dua kondisi curah hujan tersebut, Tabel 5 menyajikan frekuensi tanam beberapa komoditi sayuran dan tanaman pangan utama di Daerah Saumlaki. Jenis komoditi dimaksud adalah yang biasanya diusahakan petani dan kebutuhan airnya hanya bergantung pada hujan yang jatuh. 


\section{KESIMPULAN}

Kesimpulan-kesimpulan dari penelitian ini adalah sebagai berikut:

1. Berdasarkan perhitungan neraca air lahan, pada kondisi curah hujan berpeluang $75 \%$ untuk dilampaui defisit air tanah di Daerah Saumlaki berlangsung selama selama 6 bulan (Juni sampai November) dimana nilainya bertambah sebesar 183 $\mathrm{mm}$ atau $45,52 \%$ dibandingkan kondisi normalnya, yaitu dari $402 \mathrm{~mm}$ menjadi $585 \mathrm{~mm}$. Sebaliknya surplus air tanah berlangsung hanya sebulan (Mei) dan cenderung berkurang sebesar $686 \mathrm{~mm}$ atau 97,03\% dibandingkan kondisi normalnya, yaitu dari $707 \mathrm{~mm}$ menjadi $21 \mathrm{~mm}$.

2. Kadar air tanah yang optimum bagi tanaman pada kondisi curah hujan peluang $75 \%$ berlangsung selama 6 bulan (Januari-Juni); lebih pendek 2 bulan dibandingkan kondisi normalnya, yaitu 8 bulan (Desember sampai Juli).

3. Pada kondisi curah hujan peluang $75 \%$, musim tanam di Daerah Saumlaki berlangsung selama 7 bulan (Desember-Juni); sebulan lebih pendek dibandingkan musim tanam pada kondisi curah hujan normal, yaitu 8 bulan (Desember sampai Juli).

\section{DAFTAR PUSTAKA}

Bey, A. dan I. Las. 1991. Strategi pendekatan iklim dalam usaha tani. Dalam Kapita Selekta dalam Agrometeorologi, p.18-47. Dirjen Dikti, Depdikbud. Jakarta.

BPS. 2019. Kecamatan Tanimbar Selatan Dalam Angka. BPS Kabupaten MTB, Saumlaki.

Djufry, F. 2012. Pemodelan neraca air tanah untuk pendugaan surplus dan defisit air untuk pertumbuhan tanaman pangan di Kabupaten Merauke Papua. Jurnal Informatika Pertanian 21(1): 1-9.

Hidayat, T., Y. Koesmaryono dan A. Pramudia. 2006. Analisis neraca air dalam penentuan potensi musim tanam tanaman pangan di Provinsi Banten. Jurnal Floratek 2(1): 55-62.

Laimeheriwa, S. 2015. Analisis Data Iklim dalam Bidang Pertanian: Peluang Curah Hujan, Masa Tanam, Neraca Air Lahan dan Klasifikasi Iklim
Wilayah. Bahan Ajar Agroklimatologi, Fakultas Pertanian Universitas Pattimura, Ambon.

Laimeheriwa, S., M. Pangaribuan dan M. Amba. 2019. Analisis fenomena El Nino dan dampaknya terhadap neraca air lahan di Pulau Ambon. Jurnal Budidaya Pertanian 15(2): 111-118. DOI: 10.30598/jbdp.2019.15.2.111.

Las, I. 1992. Pewilayahan komoditi pertanian berdasarkan model iklim di Kabupaten Sikka dan Ende NTT. Disertasi. SPS-IPB, Bogor.

Mardawilis, P. Sudira, B.H. Sunarminto, dan D. Shiddiq. 2011. Analisis neraca air untuk pengembangan tanaman pangan pada kondisi iklim yang berbeda. Jurnal Agritech 31(2): 109116.

Manik, T.K. 2014. Klimatologi dasar; unsur iklim dan proses pembentukan iklim. Graha Ilmu, Yogyakarta.

Nangimah, S.L., S. Laimeheriwa, dan R. Tomasoa. 2018. Dampak fenomena El Nino dan La Nina terhadap keseimbangan air lahan pertanian dan periode tumbuh tersedia di Daerah Waeapo Pulau Buru. Jurnal Budidaya Pertanian 14(2): 66-74. DOI: $10.30598 /$ jbdp.2018.14.2.66

Paski, J.A.I., G.I.S.L. Faski, M.F. Handoyo, dan D.A.S. Pertiwi. 2017. Analisis neraca air lahan untuk tanaman padi dan jagung di Kota Bengkulu. Jurnal Ilmu Lingkungan 15(2): 83-89.

Patty, J.R. 1988. Beberapa aspek agroklimat daerah Pulau Ambon. Skripsi. Fakultas Pertanian, Universitas Pattimura, Ambon.

Schulz, E.F. 1980. Problem and Applied Hydrology. Water Res. Publ., Fort Collins, Colorado.

Sofia, D.A., H. Wibowo, dan N. Nursila. 2019. Analisis neraca air dan pergeseran jadwal tanam di daerah irigasi Cimandiri. Jurnal Teknologi Rekayasa 4(2): 193-202.

Thornthwaite, C.W and J.P. Mather. 1957. Instruction and Tables for Computing Potensial Evapotranspiration and the Water Balance. Drexel Institute of Climatology. Centerton, New Jersey.

Tim Amdal Unpatti. 2018. Laporan Andal: Kegiatan perkebunan tebu dan fasilitas pendukungnya di Kabupaten Maluku Tenggara Barat (MTB) Provinsi Maluku, Tim Amdal Universitas Pattimura, Ambon. 